\title{
Effects of lateral episiotomy on the emergence of urinary incontinence during the first postpartum year in primiparas: prospective cohort study
}

\author{
Krešimir Živković1 ${ }^{1}$, Slavko Orešković ${ }^{2}$, Anis Cerovac ${ }^{3}$, Milan Miloševićc ${ }^{4}$, Ana Tikvica Luetić ${ }^{5}$, \\ Matija Prka ${ }^{1}$, Dubravko Habek ${ }^{1}$, David Lukanovi $\hat{c}^{6}$, Giulia Spagnol ${ }^{7}$, Nikica Živkovi ${ }^{8}{ }^{8}$ \\ ${ }^{1}$ Department of Obstetrics and Gynecology, "Sveti Duh” University Hospital, University of Zagreb, School of Medicine, Zagreb, Croatia \\ ${ }^{2}$ Department of Obstetrics and Gynecology, Zagreb University Hospital Center, University of Zagreb, School of Medicine, Zagreb, Croatia \\ ${ }^{3}$ Department of Obstetrics and Gynecology, Tešanj General Hospital, School of Medicine, University of Tuzla, Tuzla, Bosnia \\ and Herzegovina \\ ${ }^{4}$ Andija Štampar School of Public Health, School of Medicine, University of Zagreb, Zagreb, Croatia \\ ${ }^{5}$ Department of Obstetrics and Gynecology," Sveti Duh" University Hospital, Catholic University of Croatia, Zagreb, Croatia \\ ${ }^{6}$ Department of Obstetrics and Gynecology, University Medical Center Ljubljana, Ljubljana, Slovenia \\ ${ }^{7}$ Department of Women and Children's Health, Clinic of Gynaecology and Obstetrics, University of Padua, Padua, Italy \\ ${ }^{8}$ Department of Obstetrics and Gynecology, Šibenik General Hospital, Šibenik, Croatia
}

\section{Abstract}

Aim of the study: Lateral episiotomy is a widely used procedure, although it is rarely mentioned in the literature and its effects on the pelvic floor are largely unexplored. The purpose of this study is to evaluate the impact of lateral episiotomy on the incidence of urinary incontinence (UI) after vaginal delivery in primiparas.

Material and methods: The study design is a prospective cohort study. The primiparas were divided into two groups. The first group consisted of women who gave birth with lateral episiotomy, while the second group included women who gave birth with an intact perineum or with perineal tears of first and second degree. Assessments of $\mathrm{UI}$ were performed at 5 and 8 months after childbirth using the International Consultation on Incontinence Questionnaire - Short Form (ICIQ-SF) questionnaire followed by the stress test.

Results: The results revealed no significant differences $(p>0.05)$ in emergence of stress urinary incontinence (SUI) between the groups at the two time points. There were no statistically significant differences in overall rate of $\mathrm{UI}$, urge urinary incontinence (UUI), or mixed urinary incontinence according to the ICIQ-SF questionnaire. The overall incontinence rate on the first examination was $24 \%$ in the episiotomy group and $36 \%$ in the perineal laceration group, although the difference was not statistically significant $(p=0.064)$. On the second examination, rates were similar and without a statistically significant difference.

Conclusions: Lateral episiotomy has a neutral effect on the onset of $\mathrm{UI}$ in primiparous women in the first year after delivery.

Key words: episiotomy, urinary incontinence, primiparas.

\section{Introduction}

Episiotomy is an obstetrical procedure that extends the vaginal vestibule during fetal expulsion. It is done to avoid severe perineal trauma and to decrease the risk of traumatic delivery for the fetus [1]. Episiotomy was widely used for many years in a routine manner and was considered safe and reliable. The first report that challenged these beliefs was published in the 1980s, claiming that episiotomy had no benefits for the pelvic floor [2]. Moreover, large studies suggested that routine implementation of episiotomy should be abandoned [3-7]. In addition, available data largely supported the theory of the negative $[8,9]$, or neutral effect $[10,11]$ of different types of episiotomies on the onset of urinary incontinence (UI). Since the effects of episiotomy on women's wellbeing remain controversial, it is important to use this operative procedure with great attention and with indication. Nowadays, the use of a restrictive approach of episiotomy, according to the obstetric indication, is recommended $[6,7]$. Lateral episiotomy is a widely used technique but is rarely mentioned in the literature and its effect on the pelvic floor is largely unexplored. This type of episiotomy is characterized by an incision, starting $1-2 \mathrm{~cm}$ from the posterior vaginal joint in the direction of the ischial tuberosity [11-13]. Most of the scientific papers deal with median and mediolateral episiotomies. 
The etiology of $\mathrm{UI}$ is multifactorial and not completely understood, although it is known that obesity, aging, and obstetric trauma are probably the most important risk factors [14]. Thom et al. reported a range of relative risk (RR) from 1.3 to 4.6 for the occurrence of $\mathrm{UI}$ in parous women as compared to nulliparous women $[15,16]$. It has been shown that most UI with onset in pregnancy or in the puerperium will spontaneously withdraw through several months after delivery due to functional recovery occurring in younger women [16]. On the other hand, in some patients, familial tendency for connective tissue weakness is an additional causal factor for stress urinary incontinence (SUI) onset [17]. It is well known that $\mathrm{UI}$ is often associated with vaginal birth. The situation of delivering a hypertrophic newborn, especially in combination with prolonged time at the pelvic outlet, could result in severe stretching or damage to the levator ani muscles and parts of the endopelvic fascia, as well as injury to the pudendal nerve $[18,19]$. The prevalence of urinary continence disorders increases with age. Rates rise from 20 to $30 \%$ in young woman to 30 to $40 \%$ in middle age and 30 to $50 \%$ in the third age [20]. Stress urinary incontinence is the most common type of incontinence in younger women with an incidence peak between years 45 and 49 [21, 22].

The aim of our study is to evaluate the impact of lateral episiotomy on UI frequency after vaginal delivery in primiparas during the first postpartum year.

\section{Material and methods}

\section{Study design and inclusion/exclusion criteria}

We conducted a prospective cohort study at the Department of Obstetrics and Gynecology, "Sveti Duh" University Hospital, Zagreb from February 2016 to October 2017 as part of the clinical trial "Effects of lateral episiotomy on the function of pelvic floor and sexual function after vaginal delivery in primiparas", which was previously registered on Australian New Zealand Clinical Trials Registry (ANZCTR). The research was approved by the Ethics Committee of the "Sveti Duh" University Hospital. All patients signed a document approved by our institution for the anonymous use of their clinical data for scientific purposes according to the European privacy law.

The puerperas were divided into two groups: - women who gave birth with lateral episiotomy,

- women who gave birth with an intact perineum or with perineal tears of first and second degree.

The inclusion criteria were as follows: primiparity, singleton pregnancies and spontaneous onset of delivery. Restrictive lateral episiotomy was used with indication. Exclusion criteria were: cesarean delivery, third- and fourth-degree perineal tears, preterm delivery, breech presentation, instrumental delivery, multiparity, multi- ple pregnancies, fetal head rotation abnormalities during delivery, deflection of the fetal head, pre-existing dyspareunia, incontinence of urine and stool during pregnancy, positive personal and family history of pelvic floor dysfunction and any surgery performed in the pelvis before the current pregnancy. Participants who became pregnant during the study or were doing exercises of pelvic floor muscles after delivery until the first pelvic examination were excluded from further research. Out of a total of 400 informed female respondents, sampling of female respondents was conducted and 100 women ( $n 1=100, n 2=100$ ) were included in each group according to the results of the test power analysis.

\section{Data collection}

The participants were called 5 and 8 months after the delivery for a pelvic floor function evaluation. The collected data were entered in the appropriate form and were related to childbirth and general characteristics of the population in both groups. The Questionnaire International Consultation on Incontinence Questionnaire - Urinary Incontinence - Short Form (ICIQ-UI-SF) was used to assess the degree of $\mathrm{UI}$ and its impact on daily life [23]. The questionnaires included a retrograde period of 4 weeks prior to arrival for evaluation ( 5 and 8 months after birth). The presence and type of symptomatic UI were defined according to the answer to question number 6 from ICIQ-UI-SF. The cough stress test was used for more precise investigation of SUI. Since the investigation included a younger population of women with recent delivery, the test was performed by a modified method. The bladder itself was not filled with $200-250 \mathrm{ml}$ of saline by a catheter, but the subjects were told to drink up to 1 liter of water 1 hour before the examination and not to empty the bladder before the examination. Before the stress test was performed, the bladder volume was assessed using 2D ellipse ultrasound (volume $=$ length $\mathrm{x}$ width $\mathrm{x}$ height $\mathrm{x} 0.52$ ), and the test was only performed at measured volumes of more than $200 \mathrm{ml}$.

\section{Statistical analysis}

The statistical analysis was performed with the SPSS version 25.0 software (www.ibm.com) An analysis of the normality of data distribution was made. Quantitative data are presented through median and interquartile ranges. The categorical data are presented through absolute frequencies and associated proportions. Differences in quantitative values between groups were evaluated by the Mann-Whitney $U$ test. Differences in categorical variables between the studied groups were analyzed by the $\chi^{2}$ test. All $p$-values less than 0.05 were considered as significant. 
Table 1. Characteristics of study population: categorical variables

\begin{tabular}{|c|c|c|c|c|}
\hline \multicolumn{2}{|c|}{ Characteristics } & \multicolumn{2}{|c|}{ Group } & \multirow{2}{*}{$\begin{array}{c}\text { Statistical } \\
\text { analysis }\end{array}$} \\
\hline & & Episiotomy & Perineal tears & \\
\hline & & $n(\%)$ & $n(\%)$ & $p$ \\
\hline \multirow{2}{*}{$\begin{array}{l}\text { Marital } \\
\text { status }\end{array}$} & Married & $77(77)$ & $85(85)$ & 0.149 \\
\hline & Unmarried & $23(23)$ & $15(15)$ & \\
\hline \multirow{3}{*}{$\begin{array}{l}\text { Mother's } \\
\text { education }\end{array}$} & High school education & $25(25)$ & $27(27)$ & 0.774 \\
\hline & College education & $12(12)$ & $9(9)$ & \\
\hline & University education & $63(63)$ & $64(64)$ & \\
\hline \multirow[t]{2}{*}{ Oxytocin } & Yes & $86(86)$ & $76(76)$ & 0.071 \\
\hline & No & $14(14)$ & $24(24)$ & \\
\hline \multirow{2}{*}{$\begin{array}{l}\text { Epidural } \\
\text { analgesia }\end{array}$} & Yes & $59(59)$ & $55(55)$ & 0.568 \\
\hline & No & $41(41)$ & $45(45)$ & \\
\hline
\end{tabular}

$n$ - number of participants, $p$ - level of significance

Table 2. Characteristics of study population: quantita

\begin{tabular}{|c|c|c|c|c|c|c|c|}
\hline & \multirow[t]{2}{*}{ Group } & \multicolumn{3}{|c|}{ Percentiles } & \multirow[t]{2}{*}{$u$} & \multirow[t]{2}{*}{$z$} & \multirow[t]{2}{*}{$p$} \\
\hline & & $25^{\text {th }}$ & Median & $75^{\text {th }}$ & & & \\
\hline \multirow[t]{2}{*}{ Age (years) } & Episiotomy & 29.0 & 31.0 & 34.0 & 4980.5 & -0.048 & 0.962 \\
\hline & Perineal tears & 28.3 & 31.0 & 34.0 & & & \\
\hline \multirow[t]{2}{*}{ BMI prior delivery $\left(\mathrm{kg} / \mathrm{m}^{2}\right)$} & Episiotomy & 25.8 & 27.9 & 29.4 & 4796.0 & -0.498 & 0.618 \\
\hline & Perineal tears & 24.8 & 26.9 & 29.8 & & & \\
\hline \multirow[t]{2}{*}{ Body weight prior pregnancy (kg) } & Episiotomy & 58.3 & 63.0 & 65.0 & 4612.0 & -0.950 & 0.342 \\
\hline & Perineal tears & 58.0 & 61.0 & 67.8 & & & \\
\hline \multirow[t]{2}{*}{ Body weight prior delivery $(\mathrm{kg})$} & Episiotomy & 72.3 & 77.0 & 82.8 & 4792.5 & -0.508 & 0.612 \\
\hline & Perineal tears & 70.0 & 75.0 & 85.0 & & & \\
\hline \multirow[t]{2}{*}{ Mother body height $(\mathrm{cm})$} & Episiotomy & 164.0 & 168.0 & 172.0 & 4968.0 & -0.078 & 0.937 \\
\hline & Perineal tears & 165.0 & 168.0 & 172.0 & & & \\
\hline \multirow[t]{2}{*}{ Newborn weight (g) } & Episiotomy & 3252.5 & 3530.0 & 3697.5 & 4587.0 & -1.009 & 0.313 \\
\hline & Perineal tears & 3215.0 & 3490.0 & 3692.5 & & & \\
\hline \multirow[t]{2}{*}{ Newborn head circumference $(\mathrm{cm})$} & Episiotomy & 34.0 & 34.5 & 36.0 & 4520.0 & -1.192 & 0.233 \\
\hline & Perineal tears & 34.0 & 34.5 & 35.0 & & & \\
\hline \multirow[t]{2}{*}{$\begin{array}{l}\text { Duration of second stage } \\
\text { of delivery (min) }\end{array}$} & Episiotomy & 58.0 & 83.5 & 120.0 & 4656.0 & -0.842 & 0.400 \\
\hline & Perineal tears & 50.0 & 80.0 & 110.0 & & & \\
\hline \multirow[t]{2}{*}{ Gestational age (weeks) } & Episiotomy & 39.04 & 40.07 & 40.57 & 4182.5 & -2.000 & 0.046 \\
\hline & Perineal tears & 39.14 & 39.86 & 40.29 & & & \\
\hline
\end{tabular}

\section{Results}

The general, anthropometric and obstetric characteristics of the participants by groups are shown in Tables 1 and 2. There were no statistically significant differences between groups except for the gestational age variable, where there was a significant difference (40.07 weeks of gestation vs. $39.86, p=0.046$ ). In the episiotomy group after 5 months, 46 women breastfed (46\%), and in the comparative group of perineal ruptures, 47 women $(47 \%)$ breastfed, which was a statistically insignificant difference $\left(\chi^{2}=0.020, p=0.887\right)$.

The initial test for assessment of SUI in both groups was a stress test. That showed no differences between the groups. In the episiotomy group, $16 \%$ of examinees had a positive result of the stress test at the first examination ( 5 months after delivery), which is comparable to $20 \%$ in the perineal tears group $\left(\chi^{2}=0.542\right.$, $p=0.462)$. At the second examination, which took place 3 months after the first evaluation, there were $13.5 \%$ positive findings in the episiotomy group and $14.9 \%$ in the perineal tears group $\left(\chi^{2}=0.071, p=0.790\right)$ (Table 3 ).

Symptomatic incontinence was classified into specific types of incontinence by the groups studied, based on the answer to question 6 from the ICIQ-UI-SF. The first examination revealed that symptomatic SUI was present in $7 \%$ of examinees in the episiotomy group 
Table 3. Stress urinary incontinence testing - stress test

\begin{tabular}{|c|c|c|c|c|c|c|c|}
\hline \multicolumn{2}{|c|}{ Stress test } & \multicolumn{4}{|c|}{ Group } & \multirow{2}{*}{\multicolumn{2}{|c|}{$\begin{array}{l}\text { Statistical } \\
\text { analysis }\end{array}$}} \\
\hline & & \multicolumn{2}{|c|}{ Episiotomy } & \multicolumn{2}{|c|}{$\begin{array}{l}\text { Perineal } \\
\text { ruptures }\end{array}$} & & \\
\hline & & $n$ & $\%$ & $n$ & $\%$ & $\chi^{2}$ test & $p$ \\
\hline \multirow{2}{*}{$\begin{array}{l}\text { Stress } \\
\text { test } 0\end{array}$} & Positive & 16 & 16 & 20 & 20 & 0.542 & 0.462 \\
\hline & Negative & 84 & 84 & 80 & 80 & & \\
\hline \multirow{2}{*}{$\begin{array}{l}\text { Stress } \\
\text { test } 1\end{array}$} & Positive & 13 & 13.5 & 14 & 14.9 & 0.071 & 0.790 \\
\hline & Negative & 83 & 86.5 & 80 & 85.1 & & \\
\hline
\end{tabular}

0 - first examination, 1 - second examination, $n$ - number of participants, $p$-level of significance

and in $16 \%$ of women in the perineal tears group $\left(\chi^{2}=3.9, p=0.05\right)$. Urge urinary incontinence (UUI) symptoms were present in $10 \%$ of examinees in the episiotomy group as compared to $16 \%$ in the perineal tears group $\left(\chi^{2}=1.592, p=0.207\right)$. Symptoms of mixed $\mathrm{UI}$ were present in both groups with a similar rate of $2 \%$. On the other hand, other non-specific incontinence symptoms were present in the episiotomy group with $5 \%$, as compared to $2 \%$ in the perineal tears group $\left(\chi^{2}=1.322, p=0.248\right)$. The overall incontinence rate was $24 \%$ in the episiotomy group and $36 \%$ in the perineal tears group $\left(\chi^{2}=3,429, p=0.064\right)$ (Table 4$)$.
At the second examination, all symptoms of different types of incontinence were found in both groups with similar prevalence (Table 4). Symptoms of SUI were found in $9.4 \%$ of women in the episiotomy group and $18.1 \%$ in the perineal tears group $\left(\chi^{2}=3.051\right.$, $p=0.081$. Symptoms of UUI were found with comparable prevalence in both groups as well (9.4\% vs. $8.5 \%)$.

The overall incontinence rate evaluated at the second examination was $26 \%$ in the episiotomy group and $29.8 \%$ in the perineal tears group $\left(\chi^{2}=0.331\right.$, $p=0.565$ ) (Table 4). The values of the median of total sum of ICIQ-UI-SF in the episiotomy group as well as in the perineal tears group were not statistically significantly different at the first $(U=4508.5, p=0.138)$ or second examination $(U=4420.0, p=0.759)$.

\section{Discussion}

According to the results of this study, lateral episiotomy in childbirth of the primiparous women does not have a protective effect on the possible occurrence of urinary continence during the first year after childbirth. There is also no adverse effect of lateral episiotomy on the investigated pelvic floor function [24, 25].

The incidence of SUI as well as other types of UI was the same in the lateral episiotomy group as in the peri-

Table 4. Symptoms of different types of incontinence by group

\begin{tabular}{|c|c|c|c|c|c|c|c|}
\hline \multirow[t]{3}{*}{ Symptoms of incontinence } & \multirow[t]{3}{*}{ No/Yes } & \multicolumn{4}{|c|}{ Group } & \multicolumn{2}{|c|}{ Statistical analysis } \\
\hline & & \multicolumn{2}{|c|}{ Episiotomy } & \multicolumn{2}{|c|}{ Perineal ruptures } & \multirow[b]{2}{*}{$\chi^{2}$ test } & \multirow[b]{2}{*}{$p$} \\
\hline & & $n$ & $\%$ & $n$ & $\%$ & & \\
\hline \multirow[t]{2}{*}{ SUI 0} & No & 93 & 93 & 84 & 84 & 3.897 & 0.050 \\
\hline & Yes & 7 & 7 & 16 & 16 & & \\
\hline \multirow[t]{2}{*}{ UUI 0} & No & 90 & 90 & 84 & 84 & 1.592 & 0.207 \\
\hline & Yes & 10 & 100 & 16 & 16 & & \\
\hline \multirow[t]{2}{*}{ MUI 0} & No & 98 & 98 & 98 & 98 & 0.000 & 1 \\
\hline & Yes & 2 & 2 & 2 & 2 & & \\
\hline \multirow[t]{2}{*}{ Other symptoms of incontinence 0} & No & 95 & 95 & 98 & 98 & 1.332 & 0.248 \\
\hline & Yes & 5 & 5 & 2 & 2 & & \\
\hline \multirow[t]{2}{*}{ Total 0} & No & 76 & 76 & 64 & 64 & 3.429 & 0.064 \\
\hline & Yes & 24 & 24 & 36 & 36 & & \\
\hline \multirow[t]{2}{*}{ SUI 1} & No & 87 & 90 & 77 & 81.9 & 3.051 & 0.081 \\
\hline & Yes & 9 & 9 & 17 & 18.1 & & \\
\hline \multirow[t]{2}{*}{ UUI 1} & No & 87 & 90 & 86 & 91.5 & 0.044 & 0.835 \\
\hline & Yes & 9 & 9.4 & 8 & 8.5 & & \\
\hline \multirow[t]{2}{*}{ MUI 1} & No & 94 & 97.9 & 92 & 97.9 & 0.000 & 0.983 \\
\hline & Yes & 2 & 2.1 & 2 & 2.1 & & \\
\hline \multirow[t]{2}{*}{ Other symptoms of incontinence1 } & No & 91 & 94.8 & 93 & 98.9 & 2.668 & 0.102 \\
\hline & Yes & 5 & 5.2 & 1 & 1.1 & & \\
\hline \multirow[t]{2}{*}{ Total 1} & No & 71 & 74 & 66 & 70.2 & 0.331 & 0.565 \\
\hline & Yes & 25 & 26 & 28 & 29.8 & & \\
\hline
\end{tabular}

$\mathrm{SUI}$ - stress urinary incontinence, $\mathrm{UUI}$ - urge urinary incontinence, $\mathrm{MUI}$ - mixed urinary incontinence1, 0 - first examination, 1 - second examination, $n$-number of participants, $p$ - level of significance 
neal tears group. Lateral episiotomy did not increase the risk of developing SUI at 5 and 8 months postpartum. The frequency of UI was the same in the lateral episiotomy group as in the lesser perineal lacerations and intact perineum group. No substantial associations between episiotomy and UI were found, which is in accordance with the majority of research on other types of episiotomy. Pelvic floor dysfunction is related to childbirth to a certain extent, although childbirth itself does not appear to be the only influencing factor $[9,26,27]$. It has not been proven that collagen weakness is the most important factor in pathogenesis of postpartum UI [28]. Although pelvic floor muscle denervation could be an etiological factor in the development of SUI, which is recorded in more than half of women after vaginal delivery, it has been shown to recover in the first year after delivery in most cases [29, 30].

A study by Wesnes et al. indicated that being incontinent during pregnancy increases the odds ratio of being incontinent six months after delivery by 3.5 times in a population of primiparous women [31]. In order to better explore the effect of delivery on pelvic floor dysfunctions, in our study we enrolled only primiparous women who had been continent through their pregnancy. We already knew that midline and mediolateral episiotomy does not protect against the onset of UI $[3,5]$, but a similar level of evidence on the use of lateral episiotomy was not published. Nevertheless, there are no studies of the mid-term effects of lateral episiotomy on the incidence of UI in the available databases. Therefore, we tried to interpret our results in comparison with other types of episiotomy.

Sartore et al. found that mediolateral episiotomy was related to lower pelvic muscle strength 3 months after vaginal delivery [11], which may be associated with emergence of SUI. Our results showed similar incidence of SUI in both study groups, suggesting that the time period of 5 and 8 months postpartum could be the optimal period for evaluation of the postpartum pelvic floor when restoration of functions is expected to be completed. This is important to note, since certain studies indicate that the symptoms will be present long term if there is no improvement in SUI 3 months after the delivery [9].

On the one hand, our results indicated high percentages of UI during the first postpartum year, confirming some previous reports on high rates of postpartum UI [28]. On the other hand, our results also revealed that women with an episiotomy had similar UI rates and scores at 5 and 8 months postpartum as well as women with no episiotomy, i.e., with perineal tears of lesser degree, suggesting that lateral episiotomy could not be a risk factor for UI occurrence after delivery. Similar results were reported by Sartore and Karacam, who found no significant difference in UI rates 3 months after delivery between women who had mediolateral epi- siotomy and those who delivered their babies without episiotomy [11, 32].

The percentage of women with SUI was, according to the diagnostic test (symptoms or stress test), in the episiotomy group 7 (16\%), and in the perineal rupture group 16 (20\%) after 5 months. In a similar study by Sartore et al., 3 months postpartum, SUI rates of $12.9 \%$ for episiotomy and $12.1 \%$ for intact perineum and lesser perineal tears were noted, but the study was performed within the framework of mediolateral episiotomy [11]. Our results showed similar incidence of $\mathrm{UI}$ in general and SUI in the primiparous women after vaginal delivery as compared to other published results $[11,33]$. Incidence of UUI is comparable to certain prevalence studies as well (4 months postpartum - 12\% in all vaginal births regardless of parity and mode of delivery) $[34,35]$. The study by Baydock showed that the risk of UUI is significantly higher in women with episiotomy (RR 1.9; 95\% Cl: 1.2-2.9, $p<0.01$ ), which was not confirmed in our study, since the incidence of UUI was similar regardless of performed episiotomy. Arrue et al. reported a general rate of SUI of 15.1\% 6 months after the vaginal birth in the primiparas, although the study was not detailed about the mode of vaginal delivery and with restrictive use of mediolateral episiotomy [36]. Episiotomy itself was not a risk factor for UI, while the most important risk factor for postpartum SUI was the occurrence of $\mathrm{UI}$ in pregnancy. Epidural analgesia did not affect the onset of $\mathrm{UI}$ in medium term, regardless of the mode of delivery [37, 38].

The main strength of the present study is exclusion of women with prior UI during pregnancy, which enabled us to perform more precise analysis of the effect of lateral episiotomy on the occurrence of postpartum UI. It has been previously reported that the prevalence of UI and SUI 6 months after delivery was similar regardless of the performance of mediolateral and lateral episiotomy [37]. Although we used different time points for investigations, our results are comparable to previously mentioned ones, with the conclusion that lateral episiotomy has no impact on the occurrence of UI and SUI in the first postpartum year. Compared to other results in one major observational study in primiparas, after 3, 6 and 9 months, UI rates were approximately 16, 24 , and $20 \%$, respectively, which is to a certain extent a similar trend. At the same time intervals, the proportions of SUI were about 10,18 , and $12 \%$, respectively $[39,40]$.

To our knowledge, this is the largest study carried out in Croatia dealing with the effect of episiotomy and vaginal birth itself on the occurrence of UI in primiparous women in the first year after vaginal delivery. Although it is well known that vaginal delivery represents a significant risk factor for the emergence of UI, lateral episiotomy has not shown any protective effect on different types of UI. A great effort was made to exclude 
any possible external factors that could affect the results of the comparison between the groups.

It is important to investigate pelvic floor dysfunction in the primiparous population as it eliminates the impact of a second birth that may exacerbate existing intrapartum injury. The first childbirth appears to have the greatest and most significant impact on the development of pelvic floor dysfunction [9]. Given that the use of lateral episiotomy in the study population was restrictive, the results of this study are even better and another reason to promote the use of restrictive lateral episiotomy.

Despite these strengths, our results have some limitations deriving from the retrospective nature of the study and the small sample size. The short time (one year) of follow-up seems to be a limitation of our study.

We recommend that postpartum pelvic floor dysfunction could be medically evaluated and treated one year after childbirth.

\section{Conclusions}

We concluded that lateral episiotomy in restrictive settings:

- represents a very good incision of the perineum with acceptable comorbidities respecting the pelvic floor functions,

- does not cause different changes of the pelvic floor in terms of emergence of UI and SUI than vaginal delivery with spontaneous minor perineal lacerations during the first year after delivery,

- has a neutral effect on the onset of UI in primiparas during the first year after delivery,

- is a safe obstetric operation when indicated.

\section{Acknowledgement}

The study was approved by the Institutional Review Board.

\section{Disclosure}

The authors report no conflict of interest.

\section{REFERENCES}

1. De Lee JB. The prophylactic forceps operation. Am J Obstet Gynecol 1920; 1: 34-44.

2. Thacker SB, Banta HD. Benefits and risks of episiotomy: an interpretative review of the English language literature, 1860-1980. Obstet Gynecol Surv 1983; 38: 322-338.

3. Group AETC. Routine vs. selective episiotomy: a randomised controlled trial. Lancet 1993; 342: 1517-1518.

4. Noventa M, Vitagliano A, Quaranta M, Borgato S, Abdulrahim B, Gizzo S. Preventive and therapeutic role of dietary inositol supplementation in periconceptional period and during pregnancy: a summary of evidences and future applications. Reprod Sci 2016; 23: 278-288.
5. Hartmann K, Viswanathan M, Palmieri R, Gartlehner G, Thorp J Jr, Lohr KN. Outcomes of routine episiotomy: a systematic review. JAMA 2005; 293: 2141-2148.

6. Franchi M, Parissone F, Lazzari C, et al. Rome wasn't built in a day: stepby-step improvement of obstetric care in the labor ward. Arch Gynecol Obstet 2020; 301: 1591-1592.

7. Carroli G, Mignini L. Episiotomy for vaginal birth. Cochrane Database Syst Rev 2009: CD000081.

8. Casey BM, Schaffer J, Bloom SL, Heartwell SF, McIntire DD, Leveno KJ. Obstetric antecedents for postpartum pelvic floor dysfunction. Am J Obstet Gynecol 2005; 192: 1655-1662.

9. Viktrup L, Lose G. The risk of stress incontinence 5 years after first delivery. Am J Obstet Gynecol 2001; 185: 82-87.

10. Handa VL, Blomquist JL, McDermott KC, Friedman S, Munoz A. Pelvic floor disorders after vaginal birth: effect of episiotomy, perineal laceration, and operative birth. Obstet Gynecol 2012; 119: 233-239.

11. Sartore A, de Seta F, Maso G, Pregazzi R, Grimaldi E, Guaschino S. The effects of mediolateral episiotomy on pelvic floor function after vaginal delivery. Obstet Gynecol 2004; 103: 669-673.

12. Laganà AS, Terzic M, Dotlic J, et al. The role of episiotomy in prevention of genital lacerations during vaginal deliveries--results from two European centers. Ginekol Pol 2015; 86: 168-175.

13. Kalis V, Laine K, de Leeuw JW, Ismail KM, Tincello DG. Classification of episiotomy: towards a standardisation of terminology. BJOG 2012; 119: 522-526.

14. Rortveit G, Daltveit AK, Hannestad YS, Hunskaar S. Urinary incontinence after vaginal delivery or cesarean section. N Engl J Med 2003; 348: 900-907.

15. Patnaik SS, Laganà AS, Vitale SG, et al. Etiology, pathophysiology and biomarkers of interstitial cystitis/painful bladder syndrome. Arch Gynecol Obstet 2017; 295: 1341-1359.

16. Thom DH, Brown JS. Reproductive and hormonal risk factors for urinary incontinence in later life: a review of the clinical and epidemiologic literature. J Am Geriatr Soc 1998; 46: 1411-1417.

17. Ulmsten U, Falconer C. Connective tissue in female urinary incontinence. Curr Opin Obstet Gynecol 1999; 11: 509-515.

18. De Lancey JO, Kearney R, Chou Q, Speights S, Binno S. The appearance of levator ani muscle abnormalities in magnetic resonance images after vaginal delivery. Obstet Gynecol 2003; 101: 46-53.

19. Snooks SJ, Swash M, Mathers SE, Henry MM. Effect of vaginal delivery on the pelvic floor: a 5-year follow-up. Br J Surg 1990; 77: 1358-1360.

20. Hannestad YS, Rortveit G, Sandvik H, Hunskaar S. A community-based epidemiological survey of female urinary incontinence: the Norwegian EPINCONT study. Epidemiology of incontinence in the country of NordTrondelag. J Clin Epidemiol 2000; 53: 1150-1157.

21. Minassian VA, Bazi T, Stewart WF. Clinical epidemiological insights into urinary incontinence. Int Urogynecol J 2017; 28: 687-696.

22. Hannestad YS, Lie RT, Rortveit G, Hunskaar S. Familial risk of urinary incontinence in women: population based cross sectional study. BMJ 2004; 329: 889-891.

23. Avery K, Donovan J, Peters TJ, Shaw C, Gotoh M, Abrams P. ICIQ: a brief and robust measure for evaluating the symptoms and impact of urinary incontinence. Neurourol Urodyn 2004; 23: 322-330.

24. Ekin M, Kaya C, Öztürk E, Cengiz H, Uzer G, Yaşar L. The level of knowledge of pelvic floor dysfunction after delivery in women who attended to a tertiary center. İstanbul Med J 2018; 19: 277-280

25. Kaya C, Cengiz H, Erdoğan VS, Helvacıoğlu C, Bilecan MS. Urinary incontinence in pregnant women and its relation with quality of life. İstanbul Med J 2018; 19: 43-46

26. Farrell SA, Allen VM, Baskett TF. Parturition and urinary incontinence in primiparas. Obstet Gynecol 2001; 97: 350-356.

27. Serati M, Salvatore S, Khullar V, et al. Prospective study to assess risk factors for pelvic floor dysfunction after delivery. Acta Obstet Gynecol Scand 2008; 87: 313-318.

28. Chaliha C, Kalia V, Stanton SL, Monga A, Sultan AH. Antenatal prediction of postpartum urinary and fecal incontinence. Obstet Gynecol 1999; 94: 689-694.

29. Ragusa A, Gizzo S, Noventa M, Ferrazzi E, Deiana S, Svelato A. Prevention of primary caesarean delivery: comprehensive management of dystocia in nulliparous patients at term. Arch Gynecol Obstet 2016; 294: 753-761. 
30. Allen RE, Hosker GL, Smith AR, Warrell DW. Pelvic floor damage and childbirth: a neurophysiological study. Br J Obstet Gynaecol 1990; 97: 770-779.

31. Wesnes SL, Hunskaar S, Bo K, Rortveit G. The effect of urinary incontinence status during pregnancy and delivery mode on incontinence postpartum. A cohort study. BJOG 2009; 116: 700-707.

32. Karaçam Z, Eroğlu K. Effects of episiotomy on bonding and mothers' health. J Adv Nurs 2003; 43: 384-394.

33. Torrisi G, Minini G, Bernasconi F, et al. A prospective study of pelvic floor dysfunctions related to delivery. Eur J Obstet Gynecol Reprod Biol 2012; 160: 110-115.

34. Franchi M, Parissone F, Lazzari C, et al. Selective use of episiotomy: what is the impact on perineal trauma? Results from a retrospective cohort study. Arch Gynecol Obstet 2020; 301: 427-435.

35. Baydock SA, Flood C, Schulz JA, et al. Prevalence and risk factors for urinary and fecal incontinence four months after vaginal delivery. J Obstet Gynaecol Can 2009; 31: 36-41.

36. Arrue $M$, Ibanez L, Paredes J, et al. Stress urinary incontinence six months after first vaginal delivery. Eur J Obstet Gynecol Reprod Biol 2010; 150: 210-214.

37. Favilli A, Laganà AS, Indraccolo $U$, et al. What women want? Results from a prospective multicenter study on women's preference about pain management during labour. Eur J Obstet Gynecol Reprod Biol 2018 228: 197-202.

38. Burgio MA, Laganà AS, Chillè G, et al. Does epidural analgesia play a role in postpartum urinary incontinence? Medium-term results from a casecontrol study. J Matern Fetal Neonatal Med 2016; 29: 1773-1776.

39. Bo K, Hilde G, Tennfjord MK, Engh ME. Does episiotomy influence vaginal resting pressure, pelvic floor muscle strength and endurance, and prevalence of urinary incontinence 6 weeks postpartum? Neurouro Urodyn 2017; 36: 683-686.

40. Laganà AS, Burgio MA, Retto G, et al. Management of the second phase of labour: perineum protection techniques. Minerva Ginecol 2015; 67: 289-296. 